DISCUSSION ON

\title{
ROAD SANITATION.
}

Opened by J. PATTEN BARBER, M.Inst.C.E., Borongh Enyineer and Surveyor, Islington,

And LOUIS C. PARIEE, M.D., D.P.I.

(FELLOW),

Medical Officer of Health, Chelsea; Consulting Sanitary Adviser to II.M. Office of Worls.

At Sessional Meeting, Wednesday, February 10th, $1 ! 104$.

\section{J. Patten Barber :}

T $\mathrm{T}$ is not with the view of being able to tell anything that is new 1 respecting roal sanitation that $I$ responded to the invitation given to me by the Council of this Institute, but that $I$ am anxions to do all I possibly can to assist in the discussion of this very important subject. In country districts it has hitherto been scarcely necessary to take into account sanitary construction in connection with road-making or maintenance, the only requirements being a sound, compact, and enduring surface, all which were met by a well-made macadamised road. But the increasing use of motor vehicles, especially of those travelling at great speed, will no doubt necessitate either the construction of dustless roads or the adoption of means for the prevention of dust being raised by vehicles from the ordiniry macadamised roads. The first of these alternatives could be complied with by replacing the ordinary macadam with tar macadam, which, though a more costly materjal, is, when laicl, freer from dust and mud than the most perfect macadam road can ever be; the second alternative would probably be provided for by treating the road with a material of an oily or tarry nature, as has been done with some success in various places during the past year. For town roads, especially those over which a great number of vehicles pass, sanitary requirements are, if not of prior, or equal importance to those of foothold and ease of traction, and assuredly should be placed no further away than next to them when 
materials are under consideration. In the case of macadamised roads the question of the priority of sanitary considerations can hardly be disputed. When such roads are largely used by velicles they are found to be incapable of resisting the effect of heavy traffic, whilst the large quantities of dust and mud produced by the combined effect of traffic and weather on the road coating have proved macadamised roads subjected to heavy traffic to be costly to keep in repair and in a cleanly state, and exceedingly difficult to maintain in a satisfactory condition for traffic, public health, or convenience.

Some few years ago I had under my charge a macadam road in Islington through which some 500 omnibuses were passing daily. The road was wide and everything possible done to keep the road clean and to prevent offensive smell from it; orderlies were employed and the road was washed thrice weekly and well drenched with deodorising liquids several times daily throughout the summer. But notwithstanding this work the smell from the road became abominable and unbearable. This case is mentioned to show that whatever care be taken it is impossible to kecp a macadamised road exposed to great traffic in a sanitary condition, and that such material is altogether unsuitable for a busy thoroughfare. Unfortunately sanitary authorities, though recognising the necessity for replacing the insanitary macadamised road by some more substantial and sanitary pavement, have to consider, as the road authority, the question of cost, and unless it can be shown that a saving in the annual expenditure on the road will result from the abolition of macadam, there is a natural hesitancy to make the needful change in view of the spectre of the next election when those ratepayers whose ideal representative is one who keeps down or reduces the rates, condemn the man who considers the public health of greater importance than the mere saving of expenditure.

If, however, the health of the people is to be the first consideration, the macadam road under heavy traffic will be found to be the most costly form of construction, excluding of course such material as flint. The cost of lieeping such a road in the same condition of repair and cleanliness as a paved road would greatly exceed the expenditure upon a road of the las mentioned character. A macadam road which it is necessary to coat so frequently as once in from two to three years should be converted into a paved road, for if all the advantages which would result from such a change were considered, it would be found that the expenditure on the work would be amply justified. There are many miles of these roads in the Metropolis from which large quantities of dust and mud are carried to the paved roads forming the main lines of traffic, so that if the necessary 
paving were done it would benefit not only those residing in and passing along the macadam roads, but also the much greater number who are found in the busiest thoroughfares. The important work of reducing the quantity of dust in the atmosphere would also be greatly assisted by the paving of such macadam roads as need coating as frequently as $I$ have stated. The road which would find favour with those who look only for one that is perfectly sanitary in construction might perhaps be described as formed of a smooth, hard, non-absorbent material, incapable of being indented or deformed by traffic, of being softened by any atmospheric temperature or disintegrated to any appreciable extent by weather or temperature, which could be laid in a homogeneous mass, without joints, and so placed and shaped as to admit of water casily flowing to the gullies. In selecting the material which would enable him to form this ideal road the engineer has not so great a number as to cause bewilderment. At present it seems there is but one which approaches the standard described, asphalt. Even this material has disadvantages which prevent the construction of a perfectly sanitary road, for as only compressed asphalt is suitable for vehicular traffic, it cannot be laid to that perfectly true shape which the ideal road should have, and the finished surface has innumerable depressions which, though of small depth, render it a little short of perfect. But the facility with which an asphalt road can be cleansed, the small amount of dust produced by its abrasion, its freedom from joints, and its non-absorptivity, seem to place it first as a material for sanitary road surfaces.

It is necessary to remind you that sanitary considerations only are under consideration, and the views expressed are not to be taken as applicable to the suitability of this material for giving a satisfactory foothold for horses shod as they are now. Wood pavements have the disadvantage of many joints and are absorbent, but the former can be greatly reduced by the use of bituminous grout for filling the joints, and the latter by creosoting the blocks uncler pressure or by the use of hard wood for paving. Hard wood, however, shrinks considerably in dry weather; the blocks then become loose and the joints enlarged. The insanitary conditions produced by these changes are easily discernible in the roads. I have never seen similar changes in creosoted deal, the reason being that the fibre of the blocks being compressed by traffic is bent over the joints and effectually seals them. A very accurately shaped road which is easily cleansed can be formed with wood blocks, but after a few years, the blocks, wearing away unequally, produce a surface not so easily kept clean as that of an asphalt road, which, owing to the greater and 
more uniform homogeneity of the material, remains with a more even surface to the end of its life.

Grinite sets, if the joints be filled with bituminous grout, make a practically non-absorbent road, but noisy and not so casily cleansol as the other paving materials mentioned. It appears that the authorities in large towns are prevented from adopting the material which would make the most sanitary road surface for the principal thoroughfares by the consideration which must be given to the necessity for providing a raul which will afford a good foothold for horses. It is worthy of consinleration, howerer, whether it is not possible for a mode of shoeing to be levised which would relieve the authorities from thus having to subordinate the health and convenience of the people to other claims.

But the most perfectly sanitary road construction is of little use unless attended by an equally perfect system of cleansing. The most suitable material for the road having heen laid with the greatest carc and skill is at once the receptacle for dirt and filth from various sources. The rreater part of the clust and filth in the principal streets is no doubt contributed by horses, and this is less objectionable in wet weather, but in dry weather, after having been ground into fine dust by the traffic, it passes into the air and becomes part of the town's atmosphere. The time is not near when lorse traction will be superseded by motors, or it might be stated that the chief source of roacl pollution was soon to be stopped. It is therefore necessary that the arrangements for producing and maintaining sanitary roads should deal with conditions as they are, and that whilst lamenting the amount of preventable dirt which is found in the streets, and taking all available measures for stopping it at its source, the best available means should be adopted for promptly clearing away everything in the shape of dust, refuse, and filth from the streets. A wellorganised system of orderlies for removing filth and refuse during the day, and a thorongh washing by hose or water-vans and machine brooms claily, is the least that can be done to busy streets, unless they have been sufficiently washed by rain, or the lowness of the air temperature renclers washing dangerous.

A plentiful and cheap supply of water is an absolute necessity for the thorough cleansing of the principal thoroughfares; and a sufficient staff of intelligent workmen, who are active, alert, and capable of exercising judgment in the execution of the work, instead of the ignorant labour with which those responsible for street cleansing are too frequently handicapped, and yet are expected to produce results which are only possible with intelligent and active workmen. The freeing of a road from semi- 
liquirl murl or slop is a simple operation, but the remoral during the claytime, from a road crowderl with traffic, of the thin film of greasy material which causes lorses to slip in a manner too well-known, is a most rlifficult, if not an impossible task. Owing to the extreme thinness of the material to be removed, it is unaffected by any tool that can be applierl to it, whilst any attempt to wash it away by first watering the road and converting the greasy substance into slop, might unduly interfere with the traffic, and would certainly be much complained of by pedestrians; although a shower of rain, which would have the same effect as the watering, being a natural occurrence would evoke no comment. Limited as he must needs be by a regard for public opinion and convenience, the borough engineer has but one remedy available for a road in the condition referred to, viz., to make a temporary surface by a plentiful sprinkling of sand or fine shingle, and to thoronghly wash the road at night. The removal from the roads of the mud and slop which are produced in unlimited quantities in wet weather, is nerer, one may safely say, carried out in a manner which satisties the public. But these requirements are frequently as reasonable as the estimates of the depth of mud on the roarls, which is always either ankle- or knee-deep. The work can be done in a reasonably efficient manner, and well enough to satisfyany reasonable critic, if a sufficiently numerous staff and the necessary amount of supervision be provided; this, however, cannot be done withont considerable expense. The public too of ten imagine that the roads can be cleansed much more frequently without the employment of more men or an increaserl expencliture. The whole difficulty of satisfactory cleansing is one of expense. It involves the supply of a proper number of men, sufficient plant and equipment, and adequate supervision. The engineer can keep the roads in a satisfactory state of cleanliness, but he cannot do it unless he is provided with the means. The evils wrought by undermanning, lack of equipment, insufficient direction, control, and supervision, are feared and condemned in every department of business and public service, except in that service which has to maintain the public roals in a proper state of cleanliness. Therefore, when the public makes its complaints about the dirty condition of our streets, it is hoped it will remember that sanitary authorities can give improverl conditions, provided the public on the one hand is willing to pay for what it asks, and the authorities on the other are willing to expend the money for employing the necessary men and staff to carry out the work.

Notwithstanding the washing and thorough cleansing of the streets in the busiest parts of the Metropolis, and the staff of orlerlies engaged in 
gathering up the filth during the day, dust is produced in large quantities in dry weather, and dispersed so widely that the air is laden with a mixture of finely powdered manure and other débris from the streets. Indoors the presence of this material is made apparent by its deposition on every surface, out of doors by the suffering produced in eyes, nose, and throat of those exposed to its action. The insanitary and offensive atmosphere produced by this dust tells more severely on persons whose visits to the crowded streets are but occasional, and who live away from the impurities which are here met with; possibly those in daily contact with it are less conscious of its effects, but the nature of the material is obviously so noxious that it cannot be regarded as non-injurious to them. The prevention of dust is without doubt of great importance in every locality, but in a crowded city where, despite all precautions, impuritics are largely produced by the countless operations carried on, every care is necessary to render the air as free as possible from solid impurities such as are given off from the streets. The patrolling of the streets during hot dry weather by rehicles, containing water to which a disinfectant has been added, specially adapted for distributing the contents in a fine spray, would probably prevent nuch of the dust which now causes nuisance; at least it seems worth a trial. Possibly, as the development of motor rehicles advances, a machine may be constructed which, while passing along the street, may, by exhaustion, carry up through a duct, whose lower end travels over the road surface, the dust and dry refuse, and clischarge it into a suitable receptacle containing water.

In the outlying districts it is possible to keep down the dust provideda sufficient staff and a sufficiently numerous equipment is provided, but there are certain days when with a high wind and a high temperature ten times the ordinary staff would be needed to keep down the dust which is raised. However, during the last twelve months experiments have been macle with a material from which I am hoping very satisfactory results will be obtained, the mixture with the water of a material which it is believed will have the effect of keeping down the dust which would otherwise be raised by the passing traffic.

Another source of impurity in our streets is the too frequent use that is made of them as a dumping ground by the costermonger and itinerant vendor, and by the shopkeeper who sweeps the refuse from his shop into the street, which he seems to regard as a suitable receptacle for the refuse from shops and premises abutting upon it. That is one of the preventable sources of filth and refuse in our streets, and one, I think, which sloould be dealt with very severely, in order that it may be put down. In that 
way much may be done to bring about a better state of cleanliness in the streets of the metropolis, which is uncloubtedly very much needed.

\section{Dr. Lovis C. Parkes.}

THE insanitary condition of the London streets has previously been the 1 subject of discussion at one of our sessional meetings, and there is probably but little that is new to be said on this well-worn theme. The Council of the Institute, however, in its wisdom has thought it appropriate to have yet another debate on the subject, chiefly $I$ presume because it realises that very little has as yet been done to inaugurate that cra of street cleanliness in the metropolis which is our desideratum, but of which the attainment appears to be so difficult.

Now firstly as to the health aspects of this question. It may be asked, Is the condition of our streets dangerous or injurious to health? And if so, what are the exact conditions that are dangerous or injurious, and how do they operate? To these questions it may be said at once that there is very little clirect evidence that any injury to health is caused by the insanitary condition of London streets, chiefly because out of the multiplicity of conditions favouring or exciting loss of health or actual diseaso amongst our population it is most difficult, if not impossible, to select a certain agent where so many participate, and to say definitely this is the exciting cause. On the other hand, with the continual advances made in Pathology and in Bacteriology, we are enabled, as time advances, with more and more certainty to select a priori certain conditions as being those which from analogy we should consider to be capable of influencing the public health, and although no complete proof is capable of demonstration, we are satisfied to regard these conditions as operative factors.

Bearing in mind then the above limitations, we may say at once that there appear to be two things intimately associated with our London streets that we may reasonably regard a priori as influencing adversely the public health. They are dust and mud, different names for essentially the same thing, for whilst dust is dried and powdered mud, mud is merely wetted dust. People say, where does all the mud in the London streets come from? The answer is that $1 \mathrm{lb}$. of dried dust, containing 30 per cent. of moisture (water), when wetted to contain 90 per cent. of moisture will weigh $7 \mathrm{lbs}$; so that, the volume being roughly proportional to the weight, a cubic foot of dry road dust, after rain has fallen, becomes 7 cubic feet of semi-liquid mud. The municipal authorities, who prior to

VOL. IXV. PART I. 
the rain had only 1 cubic foot of dry dust to remove, after the rain find themselves called upon to remove 7 cubic feet of mul. Hence the enormous economy of keeping the streets as clean as possible when dry, and so avoiding the collection and removal of countless tons of slop.

Now, as we all know, the mud and dust of London streets, especially in the great highways of traffic, is filth; it is largely composer of putrefying organic matter from horse-droppings, with its teeming swarms of putrefactive bacteria. Which is the most dangerous to health, moth or dust? To this we can safely answer, dust. Why? Well, clust attacks our mucous membranes, i.e., the delicate lining membranes of the orifices and passages leading to our internal organs. Mud cloes not; that is to say, unless the passer-by happens to have a lump of mud splashed into his eye or mouth. Then again, the dry dust of the strect not only gets into our nostrils, throats, and possibly into our lungs, but it finds its way into our houses, and, unless we are careful, settles on our food, ind by its contained bacteria sets up fermentative changes therein, which render it at times unwholesome, at other times positively dangerous. The irritating decomposing dust of the London main thoroughfares has been credited with causing sore throats (follicular tonsilitis), nasal catarrh, conjunctivitis, pneumonia, and numerous other diseases of the respiratory orgaus and passages; and it seems at least highly probable that this organic clust, which is so much in evidence in the London strects in such months as March when the wind is dry and boisterous, and which taints the whole atmosphere in the warmer months of the year when rainfall is deficient, is a contributory if not the exciting cause of these and other diseases.

The past year, 1903, supplied an experimental demonstration of the way in which relative absence of dust may conduce to a healthy season and a low death-rate. Last year was one of the healthiest years on recurd in London, and it was one of the wettest. The general death-rate was only $15 \cdot 7$ per 1,000 per annum, which is $2 \cdot 8$ per 1,000 below the average of the previous five years, whilst the rain fell almost continuously and persistently throughout the spring and summer, especially in the months which are usually the driest and most dusty, reaching a record for the year of 38 inches (Brixton), or 56 per cent. in excess of the average. The consequence of the continual downpours was that the streets were kept flushed and cleansed, accumulations of dust were washed away, and the greneral atmosphere of London was distinctly purer than is its wont.

From an interesting note in the British Medical Jounal of January 16th I may quote the following: "One feature of the rainfall of 1903 in 
London was the excessive weight of many of the individual falls, or their intensity rather than their duration; for, although the excess was (at Brixton) nearly 6 inches beyond the fall in 1879 -hitherto the wettest of the previous thirty-five years-yet the number of days with rain in 1903 was smaller than in six of the past thirty-one years. In the thirty years ending 1900 , the number of days with rin was on the arerage 166 , and the average rainfall on ench rainy day was $0 \cdot 147$ inches. Last year there were 171 days with rain, and the average fall on each of these days was 0.202 inches, or nearly half as much again as the average. Exceptionally leary falls of rain (exceeding one inch in twenty-four hours) were nearly seven times as numerous as the average; heavy falls (exceeding half an inch) were nearly twice as numerous; and moderately heavy falls (exceeding a quarter of an inch) were more than half as frequent again as the normal. In London the highest rainfall was that recorded at the Victoria and Albert Museum, Kensington, $42 \cdot 37$ inches ; the lowest that at East Ham, $32 \cdot 29$ inches. The exceptionally wet months of the year were $\mathrm{June}_{\mathrm{un}}$. July, August, and October. February, November, and December were less wet than usuil. In June three times the usual volume of rain for the whole month fell in ten days."

In 1908 , then, nature very materially supplemented the usual cleansing operations of the London municipalities, with the result that during the wet periods the roads presented a wonderfully clean appearance, and the private drains and public sewers received such a flushing at they have seldom received before. All this was most beneficial for the inhabitants of London, except perhaps for the unfortunate pcople whose basements were flooded by the storm waters which the sewers were inadequate to convey away.

The lesson of 1903 would appear, then, to be that greater attention should be given to the flushing of our main thoroughfares with water, especially in the warm and dry months of the year. This is especially important in the case of asphalt and wood-paved roadways. On such surfaces the dirt consists of little but horse droppings, which very quickly desiccate, and form a strong and pungent dust, easily raised by the wind. All wood and asphalt streets whicl are main lines of traffic should be flushed with hose and jet, and subsequently swept, every morning from March to October, unless there has been heavy rain in the night. It is very commonly the practice to sweep the streets when dry, but this is a practice not to be commended, as the operation raises clonds of dust, which settle agrain, often out of reach of the broom, and the result is not satisfactory. In very busy thoroughfares, where there is much ommibus traffic, 
I think that some disinfectant solution should be mixed with the water in the watering carts, not necessarily to disinfect, but to deodorize the dirty wood roadways, and to at least attenuate the odours about which so much complaint is made. Possibly a chlorinated solution, containing a small amount of available chlorine, would be the best for this purpose. If one gallon of "Chloros" (a solution of sodium hypochlorite containing 10 per cent. of arailable chlorine) is mixed with 1,000 gallons of water for street-watering, a dilute solution containing $0 \cdot 01$ per cent. of available chlorine is obtained. This is probably of strength sufficient to act as a deodorant in the case of wood-pared roads.

Extra flushing and cleansing of the strects means extra cost. There is no available supply of cheap, unfiltered water in London, and nothing has yet been done to draw a supply of water for flushing purposes direct from the Thames in London. The rates are alrealy very high. Is it possible to go to greater expense in this matter? I find that in 1902 in Chelsea the cost of cleansing and scavenging the streets, including watering, was about $£ 14,000$. The maintenance and repairs of the public roads, streets, ancl paths cost another $£ 14,000$. Assuming that the whole metropolis spent a proportional amount in accordance with its population, an assumption which probably errs on the side of being under the mark, as Chelsea is a little off the main traffic routes, then the annual cost of

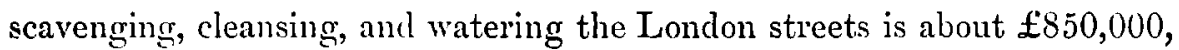
and a similar sum is spent annually in maintenance and repair.

If motor-trafic could be made to supersede horse-traction in London it seems probable that the cost of scavenging, cleansing, and watering could be reduced by half, and the cost of maintenance and repairs by a similar amount, a total saring of $\$ \$ 50,000$ per ammum. It is the horses that produce the dust, dirt, and mud, that has to be laboriously collected by hand-labour and carted to the outskirts, or barged away down the Thames. It is the horses' iron-shod feet that tear up the roadways, and render necessary the enormous amual expenditure in maintenance and repair of the streets, and their periodical renewing at short intervals. If there were no horses the slop-water from asphalt and wool-pared strects could be swept straight into the gullies and so to the sewers, and the wear and tear of the street-surfaces would be enormously reduced.

Motor-traffic, then, is a thing that the intelligent Londoner should encourage by every means in his power. It is the only real and lasting solution of the "insanitary street" problem. Enormous additional sums under existing circumstances might be spent in scavenging, cleansing, and watering, but the total result would not be very appreciable in a dry and 
hot season. We cannot expect natural causes to aid us every year, as the weather did in 1903, nor is it otherwise a consummation to be wished for.

Probably the best means of accelerating the transition from horsetraction to motor-traction would be (1) the widening of the main lines of traffic, so that vehicles could proceed at a unifurmly greater speed than at present. Carriers of groods and passengers in the streets of London will not adopt motor-traction unless it will pay; and motor-traction can only be remunerative if the increased initial cost of the motor vehicle over horse and carriage, and the higher rate of remuneration required for a motordriver as compared with a horse-driver, are counterbalancerl by the ability to make the motor-driven carriage do a proportionately larger amount of work in the same time. This necessarily involves rapid transit and quick journeys, which are only possible if blocks and delays are comparative rarities and not the every-day occurrences they now are. (2) Inasmuch as it is especially desirable that heavy two-horsed vehicles such as omnibuses and drays should be replaced by motor-driven vehicles, as it is essentially the heavy horses and heavy loads that, continually stopping and re-starting, tend to break up the surface of the streets, it would seem desirable that omnibus companies and companies or firms carrying heavy goods should be encouraged to inaugurate motor-traction by a system of municipal subsidies. If over a million and a latf sterling is spent annually in London by the ratepayers in scaveng:ng, cleansing, and repairs of the streets, necessitated chiefly by the employment of horses for all classes of traffic, $£ 100,000$ annually might be devoted to a system of subsidies, by the aid of which a portion at least of the heavy horse-tratfic might be got rid of from the streets, and the cost of cleansing, scavenging, and repairs materially reduced. A beginning once macle in this direction, the alliantages of motor-traction would soon be generally recogrnised, and in the course of a few years we might expect to see at least as many motor-vehicles as horse vehicles in the streets.

So far, this short introduction to a discussion has been chiefly in relation to the sins of the horse, the noble quadruped that has so many sins and shortcomings laid on his shoulders. But I cannot conclude without a few words about doys, man's four-footed companion. In my opinion dogs in London are an unmitigated nuisance. The disgusting condition of the pavements and sidewalks in many parts of London is due to clogs' excretal. Some years ago there were men who made a business of collecting dogs' excreta in the streets and selling it to the tamneries, where it was used in water as a solvent for hides preparatory to taming. Now I suppose dogs' excreta, or its chemical equivalent, is made in 
Germany by a chemical process, and can be put on the market cheaper than the street collector of this choice product can supply it to the tamneries. However that may be, it seems to be nobody's business now to collect the refuse, and even the municipal road sweeper passes it by. There used some years ago, prior to 1891, to be a Police ordinance that householders should clean the footways adjoining their premises. The Public Health London Act abolished all that, and placed the duty of cleaning the footways upon the locai authorities. But according to my observation the men employed by the local authorities seldom concern themselves about the sidewalks, and unless the houscholder cleans the pavement in front of his own house, nobody else troubles to do it. To clean the pavement properly, water is required, but as a rule none is available from a public source; so that to make the local authorities responsible for work, which they have not got the means of properly executing, seems to be an absurdity.

It certainly seems desirable that our borough surveyors should seriously consider as to the best means of cleansing the footways, and so performing a duty which the State has cast upon them. In order also to keep the dog nuisance within bounds, I would suggest that the London County Council apply for Parliamentary powers to put a municipal tax upon dogs in addition to the Imperial tax. A municipal tax of ten shillings per annum per $\log$ would tend to make many dog owners reflect that dogs are not indispensable adjuncts to life in this great city, and the general public would at least feel that those who create the nuisance are to some extent called upon to support the measures necessary for its abatement.

To sum up, then, our conclusions in one sentence. All animals in big towns, except of course man himself, are a nuisance. Let us do our best to get rid of them.

Mr. W. Whitaken, F.R.S. (Croydon) said he was glad that Dr. Parkes had alluded to the wet season of 1903 . Everyone thought it was a very bad year. For his part he did not. If there was one thing to which he objected it was dust, and last year was very free from it. He preferred a little rain to a great deal of dust. Now this object-lesson of last year had shown the advantage to the public health of laying the dust; he hoped it would not be forgotten by the local authorities. That lesson had been given without charge, and therefore he was afraid they perhaps might not value it as they should do. No doubt infantile mortality bad been reduced because the children last year could not play so much in dusty streets. Undoubtedly it was in the power of our large Corporations to modify the dust-nuisance, or at all events to convert it into a 
form that could be ensily remored. They all linew what a trouble dust was to the female mind; ladies would go on dusting in the home, but it should be done with damp cloths. To deal with the different degrees of blinding dust in our streets was one of the most important problems that municipalities could devote their minds to. No doubt it would cost something, but we cannot have benefits without paying for them. Indeed we should not object to pay for those conveniences, without which in big cities the people could not live comfortably or healthily. The question was one between paying a certain awount of rates and hiving a large increase in the death-rate, especially among the younger members of the community, and the gentlemen who had addressed the meeting had properly dealt with every aspect of the problem.

Mr. Simrder Morpiry (London) said there were only two points be wished to raise. The first was that the condition that was wanted in the roads of every town was that the surface should be impervious, washed and cleansed. He was told by surveyors in London that the reason we could not have these conditions was a question of cost. Now he had not even seen it stated (and it would be well worth while working out) how much would be saved in the cost of clennsing if a large area of a town were paved with impervious material and washed, as against the cheaper cost of macadam, witl the additional cost of scraping up the mud and the removal of the large quantities that collect upon its surface. Probably the balance would be on the side of the greater expense for the impervious material. Le did not think the difference would be so great that the inhabitants of a town would not be in favour of the greater expense and the better conditions. Of course, it would be necessary that the area so to be dealt with should be sufficiently large, beciuse now we bad the main streets paved with impervious material, but the side streets were macadnmised. The mud and dust from the maciadamised streets was carried to impervious surfaces of the other streets, and the saving thit ought to be effected from the better paving was not now obtainable. If in London they could not have the whole area dealt with by one uniform paving, it would be very desirable that there should be some general agreement between the authorities of the different districts of London as to how the main and important roads should be paved. He had discussed this matter with borough surveyors who had said that with varying local conditions and requirements it is impossible to have anything like a uniform pavement over so large an area as London. There might be a good deal of truth in that, but he had noticed in some cases where a road passed through two different boroughs and where the traffic conditions are identical yet different pavements are used. Maling due allowance for difference of opinion as to what is the best thing to be done, that was a difficulty which it ought to be possible to overcome. There ought to be enough experience now to determine how all main roads should be dealt with how all secondary roads should be dealt with, and how the minor streets and courts and alleys should be treated. The necessity for dealing with the poorer 
streets, especially market-streets, with some impervious pavement was obvious. Animal and vegetable refuse collected there very easily, and without frequent scavenging at considerable cost became a definite nuisance.

Mr. J. P. Wabinsaton (Borough Surveyor of Marylebone) said the main question appeared to hin to be one of money. Spealing for his (wwn district, the grent difficulty be had to meet was how to get bis authority to give him sufficient money to do the work thoroughly. When the estimates for the year were being framed the tendency always was to cut them down, not to give the department any more money for doing the work more efficiently. As to the suggestion to construct suburban roads with tar macadam, he had had some experience of this in the North of Englaud, where he had constructed $: 3 \frac{1}{2}$ miles of this form of carriage-way for a main road between two large towns. Having regard to the cost it, wore extremely well, and was certainly more sinitary than an ordinary limestone macadam road. The road was made up of limestone dipped in tar. There was much less dust after the tar macadam was laid. The question of paving for London roads was a very wide one, and one upon which very different opinions are held. Speaking personally, he should be solry to see all the carriage-ways in Ioudon asphalted. He admitted, however, that up to the present time asphalt wis by far the most sanitary and easily cleansed material, but it was very cruel fur horses, and at times dangerous for riders. Some forms of hard wood paring were also very slippery. For instance, the carriage-way in Oxford Street, by the Marble Arch, was paved with Australian wood and bad been down about $4 \frac{1}{2}$ years, but the complaints had been very numerous, several accidents had happened through horses slipping when the wood was slightly greasy. But soft wood paving was luxurious and in his opinion worth the money laid out upon it. Now Harley Street, an important thoroughtare, was paved with yellow deal treated with carbolineum. The blocks were immersed in the liquid for some 4 or 5 minutes, allowed to drip, and then laid. He had noticed that during dry weather there was less dust on the carriage-way in Harley Street than was the case in streets immediately adjoining, which were paved with wood coated with liquid tar or cresoting material. But after rain the surface of the road in Harley Street appeared to dry sooner than in the otber case. He belicred a similar experience had been gained in the City of Westminster. While he thought, therefore, there was a good deal to be said in farour of this material, he was not in agreement with the mode of applying it. $\mathrm{He}$ thought it ought to bave a longer immersion. The Marylebone Vestry paved a portion of Albany Street, alongside Trinity Church, with deal immersed for 30 minutes, and that was the best bit of deal paving in the metropolis. Owing to readjustment of boundaries that strip was not now in his borough, but while it was under his control, a period of about five years, he did not remember having to effect any repairs, no bad blocks showed up in the whole of the surface, and the same effects were noticeable here as in Harley Street. It seemed to dry 
much sooner than the adjoining paving and there was less dust upon its surface in dry weather. Ile did not agree with Dr. Parkes' suggestion as to the abolition of horses and dogs. Personally he was a lover of animals and he hoped the day was far distant when they would see no dogs or horses in the streets. He would much prefer to have the animals and pay a little more in rates to keep the streets clean. Is to washing with water from a hose, now done in several parts of London, he believed this was injurious to both soft and hard wood paving, because the water gets into the interstices, washes ont the grout, and the blocks begin to loosen. He preferred the old-fushioned method of washing by a water cart. Before the formation of the City of Westminster, Marylebone had more wood paving than any otber district in London, and these roads were washed by means of water carts and squegees. Machine brooms were tried for one or two years, but he bad found the work could be clone more efficiently and economically by hand labour. Unsatisfactory wood roads he believed were often caused by washing with hose pipes, and therefore his experience suggested the old-fashioned method was the best.

Mr. C. H. W. Bigigs (London) confessed to some cynicisin in regard to the treatment of this subject by the local authorities. The two paper's were a disgrace, not to the gentlemen who bad read them, but a disgrace to England, to sanitarians, and to civilization. Here was an expert getting up and saying that we could have sanitary streets if someone would only pay the cust, and this at the beginuing of the 20th century. He thought the public did not lose their tempers often enough. We know better than to keep our strects in this state, yet were content to breathe the dust every summer's day. If they could teath the people that this extra expenditure would pay them, then the money would be forthcoming. Would better streets pay the public? Tes, because it was a distinct money value to have men healthy during their working lives. That money value would be found to be more than the extra cost of lieeping the streets sanitary and clean. Drive that into the heads of the public and the money would be supplied. This question had been discussed for the last 25 years and the cry was always the same, that the people would not give the money, not for stronger and longer lives, not for means for doing more and better work. If anything could be said that night that would induce people to regard this question differently then a great general benefit would be conferred on the community. With regard to macadam, they would find it impossible to make macadam-streets to wear satisfactorily with heavy traffic; and they could not be kept sanitary. Then the logic of the case was that they should be done aray with in such places as London. Tarred macadam was a better material everyone knew, but we do not use it, or if we do use it at all we do not use it to the best advantage. In places like Cromer and Harrogate many miles of roads of this construction would be found bearing a firily heavy traffic. It wears well and is sanitary. He had long ago advocated motor-traffic, because by its introduction 
we should get perfect street surfaces, the contact between the wheels of a motor vehicle would be altogether different in character from the rumming and scriping contact of horses' hoofs. 'The streets would last longer and the cost would be less. Slipperiness on good surfaced roads had been referred to, and he was of opinion there were two people to deal with this evil, the malier of the streets and the shoel of horses. If the shoesmith will put upon horses the very worst possible form of shoe, then although the waker of the street might be doing his duty the shoeswith was not. If horses were properly shod it would be impossible for them to slip. People who drive valuable horses ought to insist upon their being shod properly. He thought it was disgraceful that at this period of our civilization it should be necessary to hare two such papers as those read that erening in order to drum it into the heads of the people to pay money and pay it quickly.

Mr. T. Laxiston (Marylebone), as a maker of roads, bore testimony to the dust and mud-producing qualities of the macadam road. It stood to reason that hard wood must be more slippery than soft wood, and it must also be more noisy. At Nottingham tar-macadam was used in nearly all the streets, and the result was that that city liad splendid roads, wbich stood a great deal of wear, as was proved where it was used on the road to and from the Trent Bridge. Personally he was in favour of asphalt, especially for the coming motor traffic, and there was no reason why it should not be all asphalt in London, fine sand or powdered shell correcting the tendency to slipperiness. Horses were at present shod wrongly, and they could be shod to meet the requirements of asphalt streets, which were sanitary and clean.

The Chairanas (The Rt. Hon. Lord Monkswell) said that it had given him a great deal of pleasure to be present that evening and to hear the interesting discussion which had taken place. To a great extent he sympathised with Mr. Waddington, who deprecated the suggestion that horses and dogs slould be made to disappear from our streets in this great metropolis. Was it to be also suggested that every other animal, including the birds, should follow suit? Then cats bad also to be taken into consideration. He had listened with interest to the rather fierce lecture of Mr. Biggs on what might be called the pigheadedness of the public. Someone had referred to the spectre of the "next municipal election." Well, that spectre was before him, and perhaps Mr. Biggs would understand that consequently it was difficult for him to speals his mind, even if he were in entire agreement with what bad been advanced in the denouncement of the human race in general. Now, the medical profession was always making wonderful discoveries, and Dr. Parkes had made two discoveries that seemed to be rather remarkable. Last year there were two things that the average Briton used very bad language over, one was the rain and the other was motor-cars. In regard to motor-cars he had his own special grievance, inasmuch 
as he was nearly lilled in the early autumn in a motor-car accident. He was not therefore quite prepared to give the motor-car that enormous subsidy suggested by Dr. Parkes. The medical profession, however, had discovered in the two things, rain and motor-cars, the greatest possible benefactors to the human race. He might express his general concurrence with the views that had been put forward that evening, vi\%, that in all probability a considerable increase of expenditure is desirable in the cleansing of the roads and streets. That was not, however, the only direction in which increased expenditure might be desirable.

Mr. J. Patren Barber (Islington), in reply, said it was true that year after year they preached the same sermon, and perhaps the whole matter was one which time alone would settle. As his lordship had suggested, education was required. When those who took a broad-minded riew, as many did, wanted a better state of things, roads kept in better repair, macadam and other insanitary materials abolished, the dust kept down, refuse kept out of the streets, these reforms would come. Public wants were increasing, and rightly so, but he was afraid general intelligence was not increasing, because there were many persons who were unable to see that they could not get these things at the same cost as the things with which they now had to be content. Half a moment's consideration should convince anyone that if scavenging was to be done three or four times instead of once a great deal more money must be spent. A man must admit that if he wants double what he now has he must pay something like double the cost. This was a matter of education. Happily there were men who were absolutely fearless in spending money on right objects, and who were not afraid of the pains and penalties with which they were threatened when next they asked for the votes of the electors. To his mind there was too great a cry made of reduced rates and reduced expenditure by those who knew it was impossible to obtain these reductions, and why that cry was always raised when elections were approaching he did not understand. Those who bad studied London problems must know that the expenditure on all matters relating to public health and convenience in this great city must of necessity increase as the population increased, the amount of traffic increased, and the wear and tear on the roads increased.

Dr. L. Pankes (Chelsea), in reply, said it seemed to him there might be a little more efficiency in the work done now. The idea still prevailed among some London municipalities that any class of man was good enough for cleansing the London streets. That was not so. It really paid better to have young and intelligent men to do even work of that sort. Care and intelligence was required to do the work properly, and it paid to have it so done. Cheap labour was a great mistake in most things, and he was sure it was so in municipal sanitation. 